\title{
Micropropagation of Ficus carica L. through Tissue Culture System
}

\author{
Patah, F.K.A., Hasbullah, N.A., Idris, H., Radzuan, N.S. and Mohammad Mohd Lassim
}

\begin{abstract}
Ficus spp. is one of Moraceae family which natively to Westerns Asia and distributed worldwide and economically important. The richness of nutrients and latex cells make this plant possessed many pharmacological effects which is importantly to medicinal and drugs industries. The demand for this plant is very high despite the production of fig is very inconsistent from year to year. So, this study have determined the highest shoot regeneration recorded when the stem explant was cultured in MS medium supplemented with $1.0 \mathrm{mg} / \mathrm{L}$ of BAP $+0.0 \mathrm{~g} / \mathrm{L}$ NAA with $2.57 \pm 0.997$. For callus induction, the highest fresh weight in stem explant was $2.28 \pm 0.239$ obtained when cultured in MS medium supplemented with $0.5 \mathrm{mg} / \mathrm{L} \mathrm{BAP}+1.0 \mathrm{mg} / \mathrm{L}$ NAA, shoot explant was $1.0 \mathrm{mg} / \mathrm{L}$ BAP $+0.5 \mathrm{mg} / \mathrm{L}$ NAA with fresh weight $2.39 \pm 0.134 \mathrm{~g}$, petiole explant was $1.42 \pm 0.230 \mathrm{~g}$ in $\mathrm{MS}$ medium supplemented with $0.5 \mathrm{mg} / \mathrm{L} \mathrm{BAP}+1.0 \mathrm{mg} / \mathrm{L}$ NAA and root explant was was $1.43 \pm 0.148 \mathrm{~g}$ when explant was cultured on $1.0 \mathrm{mg} / \mathrm{L} \mathrm{BAP}+$ $1.0 \mathrm{mg} / \mathrm{L}$ NAA.
\end{abstract}

Index Terms - Ficus carica L., Moraceae, Tissue Culture, Growth Regulators, Explants.

\section{INTRODUCTION}

FICUS carica is one of the species in the genus Ficus or Ficeae which belong to Moraceae. Moraceae is an angiosperm plant family which very rich in edible species and characterized by latex in all parenchymatous tissue, unisexual flowers, anatropous ovules, and aggregated drupes or achenes [2]. Ficus carica believed was originated in Middle East because it is one of the first plant was cultivated by humans because its important crop worldwide for dry and fresh consumption. Some studies stated that this species is native to Western Asia [4], Mediterranean region [10], Africa, and Europe [1].

Nowadays, most of the world's fig production occurs in Mediterranean. The availability of figs in various regions because it is recognized to essay the adeptness to linger predominant shortfall and blend salinity highlight making it suitable species for cultivation in semi-arid environment such as Middle East and Mediterranean [6].

Fadhlul Khaliq Ab Patah 1 is with Department of Agriculture Science, Faculty of Technical and Vocational (FTV), Universiti Pendidikan Sultan Idris (UPSI), Tanjong Malim, Perak, Malaysia.

Dr Nor Azlina Hasbullah2, is with Department of Agriculture Science, Faculty of Technical and Vocational (FTV), Universiti Pendidikan Sultan Idris (UPSI), Tanjong Malim, Perak, Malaysia.

Husna Idris3 is with Department of Agriculture Science, Faculty of Technical and Vocational (FTV), Universiti Pendidikan Sultan Idris (UPSI), Tanjong Malim, Perak, Malaysia.

Prof. Dr. Mohammad Mohd Lassim, is with Faculty of Sustainable Agriculture (Sandakan Campus), Universiti Malaysia Sabah (UMS), 90000, Sandakan, Sabah, Malaysia
The beneficial of Ficus carica in its nutritional content and secondary metabolites gain interest among researchers as medicinal plant in pharmaceutical purpose. Ficus carica as a fruit have a very high safety profile which contain of numerous of nutrients including calcium, iron, magnesium, phosphorus, potassium, sodium, zinc, thiamin, riboflavin, niacin, vitamin B6, vitamin B12, vitamin A, vitamin C, and Folate [15]. The edible fruit of Ficus were traditionally used for treatment of hemorrhoids, insect stings, gout, ulcers and skin infections such as warts and viruses. It also are recommended for people suffering from constipation, nutrient for pregnant women and for mental and physical exhaustion. They are considered as antipyretic, tonic, purgative, alexiteric, aphrodisiac, lithontriptic, anti-inflammatory, expectorant, diuretic, and used for treatment on pharyngitis, gastritis, bronchitis, irritative cough, weakness, paralysis, thirst, disease of the liver and spleen, pain in the chest, to cure piles, to stimulate growth of hair, and for leprosy and nose bleeding [1].

Thus, the relationship between consuming natural and functional food and healthy life causing the demand on fig are increased through years. Turkey is a major figs producer and exporter in the world with total production of 270,830 tonnes of figs with $26 \%$ of the world production and $36 \%$ of exports [11]. In 2015, Turkey remain it spot as a leader in fig production and consumption [7]. However, the production of fig in Turkey dropped to 262, 644 tonnes with only $20 \%$ of output are recorded in 2016 [10]. In addition, the production of common fig in Jordon also has dropped more than 20 -folds during the last five decades [13].

The conventional method has been used widely in propagating Ficus carica even in mass-scale production. However, Dessoky, Attia, and Mohammed [6] has stated that the propagation by conventional methods such as cuttings, grafting and layering is slow, limited and results in poor rooting which only $20-30 \%$ of the cutting survive, and also contributed significantly to the dissemination of pathogens which affect the yield potential of the crop.

Recently, plant tissue culture approach have been used widely and one of the most rapidly growing area of biotechnology because it is high potential to develop improved crops and ornamental plants. This technique has already helped in the green revolution by improving the crop yield and quality [14]. So, the purpose of this study is to establish an alternative way in help micro propagating Ficus carica through tissue culture system in mass-scale production. 


\section{MAterials AND MethodS}

\section{A. Seed Germination and Explant Preparation}

Explants were cultured from sterilized seeds from fresh fig in basic medium solution with $6.0 \mathrm{pH}$. Seeds were sterilized by running the seeds under the tap water to excess the dirt and pulp from the seeds. Then, used was used for $30 \%$ of sodium hyperchlorite in in 5 minutes, rinsed with distilled water for 5 times, and aseptically rinsed with $70 \%$ of alcohol and sterile distilled water in laminar airflow cabinet.

\section{B. Media and Culture Condition}

Basic Seeds in basic medium solution were supplied with $100 \mathrm{ml}$ of macronutrient, $10 \mathrm{ml}$ of micronutrient, $10 \mathrm{ml}$ of vitamin, $10 \mathrm{ml}$ of iron, $30 \mathrm{~g}$ of sucrose and solidified by $8 \mathrm{~g}$ of technical agar in $1000 \mathrm{ml}$ of distilled water. The explants were incubated in constant condition, 16 hours of artificial light and 8 hours of darkness at $23 \pm 3{ }^{\circ} \mathrm{C}$. After 8 to 12 weeks the explants were ready to be tested on several combination of hormones.

\section{Shoot Regeneration and Callus Induction}

In this study, there were 4 types of explants (shoot, stem, root, and petiole) tested in several combination of 6-Benzylaminopurine (BAP) and Napthaleneacetic acid (NAA). The explants were cut into small fragments about 1.0 $\mathrm{cm} \times 1.0 \mathrm{~cm}$ and were placed on the top of basic medium that contained desired combination of hormones. The explants were incubated in constant photoperiod condition, 16 hours of artificial light and 8 hours of darkness at $23 \pm 3{ }^{\circ} \mathrm{C}$.

\section{Statistical Analysis}

The experiments were conducted in completely randomized design (CRD) and there were 30 replicates per treatment and each treatment was repeated in three sets. The data were analyzed by Analysis of Variance (ANOVA) using Duncan's multiple range test at $\mathrm{p}=0.5$.

\section{RESULTS AND DISCUSSION}

\section{A. Effects of Combination of BAP and NAA on Shoot Regeneration}

Shoot regeneration was only successfully being regenerated from stem explants in basic medium with addition of hormones. Table I shows the effect of different concentration and combination of BAP and NAA on stem explant cultured on MS medium for shoot regeneration. The best combination of hormone that gave optimum shoot growth was $2.57 \pm 0.997$ when the explant was cultured in MS medium supplemented with 1.0 $\mathrm{mg} / \mathrm{L}$ of BAP $+0.0 \mathrm{~g} / \mathrm{L}$ NAA. However, Table II shows that the concentration range of BAP from $0.5 \mathrm{mg} / \mathrm{L}$ to $2.0 \mathrm{mg} / \mathrm{L}$ have a remarkable respond in shoot regeneration of Ficus carica when compare to control and others combination hormones. In another study, Hesami, Daneshvar, Yoosefzadeh-Najafabadi, and Alizadeh [8] stated that MS medium supplemented with 0.5 $\mathrm{mg} / \mathrm{L}$ BAP had the longest shoot length per explants in Ficus religiosa..This show that cytokinin play an important role in promoting and multiplication of shoots.
Meanwhile, the lowest number of shoots was $0.07 \pm 0.118$ when the stem explant was cultured on MS medium with combination hormones of $2.0 \mathrm{mg} / \mathrm{L}$ of BAP $+0.5 \mathrm{mg} / \mathrm{L}$ NAA when compared to control. This happened when there presence of auxin hormones. Previous study, Danial, Ibrahim, Brkat and Khalil [4] found that the optimal concentration for shoot multiplication ranged between 0.5 and $3.0 \mathrm{mg} / \mathrm{L}$ BAP. Darwesh, Bazaid and Samra [5] have stated that the best number of leaves was obtained from medium supplemented with $3.0 \mathrm{mg} / \mathrm{L} \mathrm{BA}$ combined with $\mathrm{GA}_{3}$ at $1.0 \mathrm{mg} / \mathrm{L}$ from shoot explants. Bayoudh, Labidi, Madjoub, and Mars [3] also stated that the highest shoot multiplication were provided by medium contain $0.5 \mathrm{mg} / \mathrm{L}$ of $\mathrm{BAP}$ and $1.0 \mathrm{mg} / \mathrm{L}$ of NAA.

However, in control condition which absence of hormone concentration show that the stem explant was able to response to the concentration of nutrients but the growth on the shoot were stopped after 4 weeks and necrosis.

Thus, Hesami, Daneshvar, Yoosefzadeh-Najafabadi, and Alizadeh [8] has stated that high and low ratio of auxin/cytokinin promote root and shoot formation respectively andseems both hormones playing an important role in in vitro organogenesis.

TABLE I: EFFECTS OF DIFFERENT CONCENTRATION AND COMBINATION OF BAP AND NAA ON STEM EXPLANT CULTURED ON MS MEDIUM ON SHOOT REGENARATION

\begin{tabular}{|c|c|}
\hline Treatments (mg/L) & $\begin{array}{c}\text { Number of Shoots } \\
(\text { Mean } \pm \text { SE })\end{array}$ \\
\hline $0.0 \mathrm{mg} / \mathrm{L} \mathrm{BAP}+0.0 \mathrm{mg} / \mathrm{L} \mathrm{NAA}$ & $1.3 \pm 0.356_{\mathrm{c}, \mathrm{d}}$ \\
\hline $0.5 \mathrm{mg} / \mathrm{L} \mathrm{BAP}+0.0 \mathrm{mg} / \mathrm{L} \mathrm{NAA}$ & $0.77 \pm 0.563_{\mathrm{e}}$ \\
\hline $1.0 \mathrm{mg} / \mathrm{L} \mathrm{BAP}+0.0 \mathrm{mg} / \mathrm{L} \mathrm{NAA}$ & $2.57 \pm 0.997 \mathrm{a}$ \\
\hline $1.5 \mathrm{mg} / \mathrm{L} \mathrm{BAP}+0.0 \mathrm{mg} / \mathrm{L} \mathrm{NAA}$ & $1.87 \pm 0.830_{\mathrm{c}}$ \\
\hline $2.0 \mathrm{mg} / \mathrm{L} \mathrm{BAP}+0.0 \mathrm{mg} / \mathrm{L} \mathrm{NAA}$ & $2.13 \pm 0.831_{b}$ \\
\hline $0.5 \mathrm{mg} / \mathrm{L} \mathrm{BAP}+0.5 \mathrm{mg} / \mathrm{L} \mathrm{NAA}$ & $0.23 \pm 0.124_{\mathrm{f}, \mathrm{g}}$ \\
\hline $1.0 \mathrm{mg} / \mathrm{L} \mathrm{BAP}+0.5 \mathrm{mg} / \mathrm{L} \mathrm{NAA}$ & $0.73 \pm 0.421_{\mathrm{e}}$ \\
\hline $2.0 \mathrm{mg} / \mathrm{L} \mathrm{BAP}+0.5 \mathrm{mg} / \mathrm{L} \mathrm{NAA}$ & $0.07 \pm 0.067_{\mathrm{i}}$ \\
\hline $0.5 \mathrm{mg} / \mathrm{L} \mathrm{BAP}+1.0 \mathrm{mg} / \mathrm{L} \mathrm{NAA}$ & $0.17 \pm 0.118_{\mathrm{h}}$ \\
\hline $1.0 \mathrm{mg} / \mathrm{L} \mathrm{BAP}+1.0 \mathrm{mg} / \mathrm{L} \mathrm{NAA}$ & $0.37 \pm 0.305_{\mathrm{f}}$ \\
\hline
\end{tabular}

Mean \pm SE, $n=30$. Mean is different significantly at $p=0.5$ 


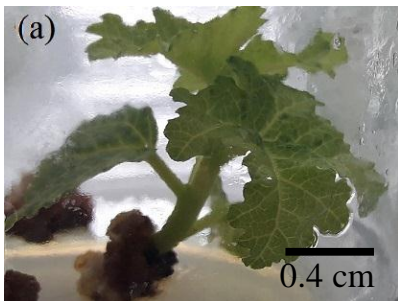

(b)

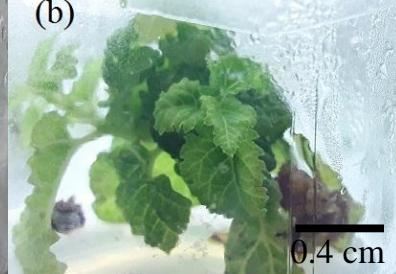

Fig. 1 shoot regeneration on (a) stem explant cultured on $1.0 \mathrm{mg} / \mathrm{L}$ $\mathrm{BAP}+0.0 \mathrm{mg} / \mathrm{L}$ NAA for 4 week (b) for 8 week

\section{B. Effects of Combination of BAP and NAA on Type of explant for Callus Induction}

Callus inductions from stem explant been achieved successfully achieved in Ficus carica. The Table II below shows the effect of different concentration and combination of BAP and NAA on stem explant cultured on MS medium for callus induction. The highest fresh weight was $2.28 \pm 0.239 \mathrm{~g}$ per stem explant obtained when cultured in MS medium supplemented with $0.5 \mathrm{mg} / \mathrm{L} \mathrm{BAP}+1.0 \mathrm{mg} / \mathrm{L}$ NAA. Meanwhile, the lowest weight fresh was obtained from MS medium supplemented with $0.5 \mathrm{mg} / \mathrm{L}$ NAA was $0.16 \pm 0.051 \mathrm{~g}$.

TABLE II: EFFECTS OF DIFFERENT CONCENTRATION AND COMBINATION OF BAP AND NAA ON STEM EXPLANT CULTURED ON MS MEDIUM ON CALLUS

\begin{tabular}{lccc}
\multicolumn{1}{c}{ Treatments $(\mathrm{mg} / \mathrm{L})$} & $\begin{array}{c}\text { INDUCTION } \\
\text { Weight }(\mathrm{g}) \\
\text { (Mean } \pm \mathrm{SE})\end{array}$ & $\begin{array}{c}\text { Colour } \\
\text { of } \\
\text { callus }\end{array}$ & $\begin{array}{c}\text { Structure } \\
\text { of callus }\end{array}$ \\
\hline $\begin{array}{l}0.0 \mathrm{mg} / \mathrm{L} \mathrm{BAP}+0.0 \\
\mathrm{mg} / \mathrm{L} \mathrm{NAA}\end{array}$ & $0.06 \pm 0.016_{\mathrm{g}}$ & Brown & Friable \\
$\begin{array}{l}0.0 \mathrm{mg} / \mathrm{L} \mathrm{BAP}+0.5 \\
\mathrm{mg} / \mathrm{L} \mathrm{NAA}\end{array}$ & $0.16 \pm 0.051_{\mathrm{f}}$ & Brown & Friable \\
$\begin{array}{l}0.5 \mathrm{mg} / \mathrm{L} \mathrm{BAP}+0.5 \\
\mathrm{mg} / \mathrm{L} \mathrm{NAA}\end{array}$ & $1.56 \pm 0.138_{\mathrm{c}}$ & Green & Sturdy \\
$\begin{array}{l}1.0 \mathrm{mg} / \mathrm{L} \mathrm{BAP}+0.5 \\
\mathrm{mg} / \mathrm{L} \mathrm{NAA}\end{array}$ & $1.85 \pm 0.217_{\mathrm{c}}$ & Cream & Sturdy \\
$\begin{array}{l}1.5 \mathrm{mg} / \mathrm{L} \mathrm{BAP}+0.5 \\
\mathrm{mg} / \mathrm{L} \mathrm{NAA}\end{array}$ & $1.11 \pm 0.270_{\mathrm{d}}$ & Cream & Sturdy \\
$\begin{array}{l}0.5 \mathrm{mg} / \mathrm{L} \mathrm{BAP}+1.0 \\
\mathrm{mg} / \mathrm{L} \mathrm{NAA}\end{array}$ & $2.28 \pm 0.239_{\mathrm{a}}$ & Cream & Sturdy \\
$\begin{array}{l}1.0 \mathrm{mg} / \mathrm{L} \mathrm{BAP}+1.0 \\
\mathrm{mg} / \mathrm{L} \mathrm{NAA}\end{array}$ & $2.06 \pm 0.162_{\mathrm{b}}$ & Cream & Sturdy \\
$\begin{array}{l}1.5 \mathrm{mg} / \mathrm{L} \mathrm{BAP}+1.0 \\
\mathrm{mg} / \mathrm{L} \mathrm{NAA}\end{array}$ & $0.96 \pm 0.123_{\mathrm{e}}$ & Cream & Sturdy \\
\hline \hline
\end{tabular}

Mean $\pm \mathrm{SE}, \mathrm{n}=30$. Mean is different significantly at $\mathrm{p}=0.5$ (a)

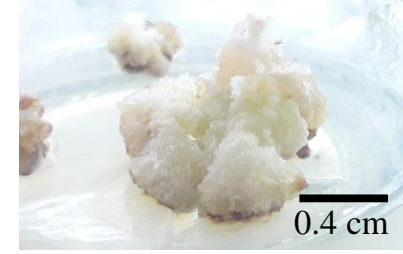

(b)

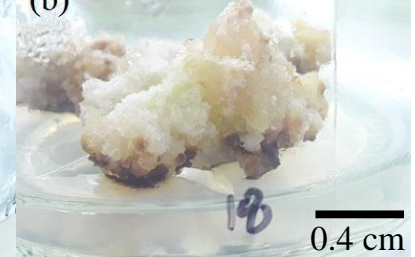

Fig. 2 shows that the growth of callus from stem explant cultured on $0.5 \mathrm{mg} / \mathrm{L} \mathrm{BAP}+1.0 \mathrm{mg} / \mathrm{L}$ NAA (a) for 4 week (b) for 8 week

Table III below shows the effects of different concentration and combination of BAP and NAA on shoot explant cultured on MS Medium for callus induction. For shoot explant, callus induction have been successfully achieved on MS medium supplemented with $1.0 \mathrm{mg} / \mathrm{L} \mathrm{BAP}+0.5 \mathrm{mg} / \mathrm{L}$ NAA with fresh weight $2.39 \pm 0.134 \mathrm{~g}$. Meanwhile the lowest when the shoot explant was cultured on $0.0 \mathrm{mg} / \mathrm{L} \mathrm{BAP}+0.5 \mathrm{mg} / \mathrm{L}$ NAA with fresh weight $0.19 \pm 0.11 \mathrm{~g}$.
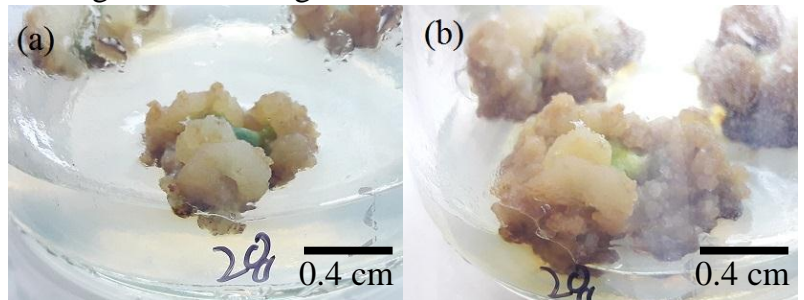

Fig. 3 shows that the growth of callus from shoot explant cultured on $1.0 \mathrm{mg} / \mathrm{L} \mathrm{BAP}+0.5 \mathrm{mg} / \mathrm{L}$ NAA (a) for 4 week (b) for 8 week.

Danial, Ibrahim, Brkat and Khalis [4] found that the highest callus recorded in their study was $1.823 \mathrm{~g}$ when leave segment was cultured on MS medium supplemented with $0.4 \mathrm{mg} / \mathrm{L}$ kinetin $+4.0 \mathrm{mg} / \mathrm{L} 2,4-\mathrm{D}$ and the lowest at $4 \mathrm{mg} / \mathrm{L}$ kinetin +0.4 $\mathrm{mg} / \mathrm{L} 2$ 2,4-D with weight $0.533 \mathrm{~g}$. Hormone 2,4-D was essential for callus induction and addition of kinetin in certain concentration will increase the callus growth in leaf culture.

TABLE III: EFFECTS OF DIFFERENT CONCENTRATION AND COMBINATION OF BAP AND NAA ON SHOOT EXPLANT CULTURED ON MS MEDIUM ON CALLUS INDUCTION

\begin{tabular}{lccc}
\multicolumn{1}{c}{ Treatments $(\mathrm{mg} / \mathrm{L})$} & $\begin{array}{c}\text { Weight }(\mathrm{g}) \\
(\text { Mean } \pm \mathrm{SE})\end{array}$ & $\begin{array}{c}\text { Colour } \\
\text { of } \\
\text { callus }\end{array}$ & $\begin{array}{c}\text { Structure } \\
\text { of callus }\end{array}$ \\
\hline $\begin{array}{l}0.0 \mathrm{mg} / \mathrm{L} \mathrm{BAP}+0.0 \\
\mathrm{mg} / \mathrm{L} \mathrm{NAA}\end{array}$ & $0.00 \pm 0.000_{\mathrm{g}}$ & $\mathrm{nr}$ & $\mathrm{nr}$ \\
$\begin{array}{l}0.0 \mathrm{mg} / \mathrm{L} \mathrm{BAP}+0.5 \\
\text { mg/L NAA }\end{array}$ & $0.19 \pm 0.011_{\mathrm{f}}$ & Brown & Friable \\
$\begin{array}{l}0.5 \mathrm{mg} / \mathrm{L} \mathrm{BAP}+0.5 \\
\mathrm{mg} / \mathrm{L} \mathrm{NAA}\end{array}$ & $1.51 \pm 0.177_{\mathrm{c}}$ & Cream & Sturdy \\
$\begin{array}{l}1.0 \mathrm{mg} / \mathrm{L} \mathrm{BAP}+0.5 \\
\mathrm{mg} / \mathrm{L} \mathrm{NAA}\end{array}$ & $2.39 \pm 0.134_{\mathrm{a}}$ & Cream & Sturdy \\
$\begin{array}{l}1.5 \mathrm{mg} / \mathrm{L} \mathrm{BAP}+0.5 \\
\mathrm{mg} / \mathrm{L} \mathrm{NAA}\end{array}$ & $1.01 \pm 0.229_{\mathrm{d}}$ & Cream & Sturdy \\
$\begin{array}{l}0.5 \mathrm{mg} / \mathrm{L} \mathrm{BAP}+1.0 \\
\mathrm{mg} / \mathrm{L} \mathrm{NAA}\end{array}$ & $2.05 \pm 0.206_{\mathrm{b}}$ & Cream & Sturdy \\
$\begin{array}{l}1.0 \mathrm{mg} / \mathrm{L} \mathrm{BAP}+1.0 \\
\mathrm{mg} / \mathrm{L} \mathrm{NAA}\end{array}$ & $0.45 \pm 0.155_{\mathrm{e}}$ & Cream & Sturdy \\
$\begin{array}{l}1.5 \mathrm{mg} / \mathrm{L} \mathrm{BAP}+1.0 \\
\mathrm{mg} / \mathrm{L} \mathrm{NAA}\end{array}$ & $1.10 \pm 0.135_{\mathrm{d}}$ & Cream & Sturdy \\
\hline \hline
\end{tabular}

Mean \pm SE, $n=30$. Mean is different significantly at $\mathrm{p}=0.5 . \mathrm{nr}=\mathrm{non}$ responsive

In this study, most of the root and petiole explants were not very responsive to most hormones concentrations. However, the highest fresh weight recorded for petiole explants was $1.42 \pm 0.230 \mathrm{~g}$ in MS medium supplemented with $0.5 \mathrm{mg} / \mathrm{L} \mathrm{BAP}$ $+1.0 \mathrm{mg} / \mathrm{L}$ NAA while the lowest weight was $0.12 \pm 0.048 \mathrm{~g}$ when cultured on MS medium supplemented with $2.0 \mathrm{mg} / \mathrm{L}$ BAP $+1.0 \mathrm{mg} / \mathrm{L}$ NAA. For root explants, the highest fresh weight recorded was $1.43 \pm 0.148 \mathrm{~g}$ when explant was cultured on $1.0 \mathrm{mg} / \mathrm{L} \mathrm{BAP}+1.0 \mathrm{mg} / \mathrm{L} \mathrm{NAA}$ and the lowest fresh weight was $0.01 \pm 0.005 \mathrm{~g}$ cultured on MS medium supplemented with $1.5 \mathrm{mg} / \mathrm{L}$ BAP + $1.0 \mathrm{mg} / \mathrm{L}$ NAA. 


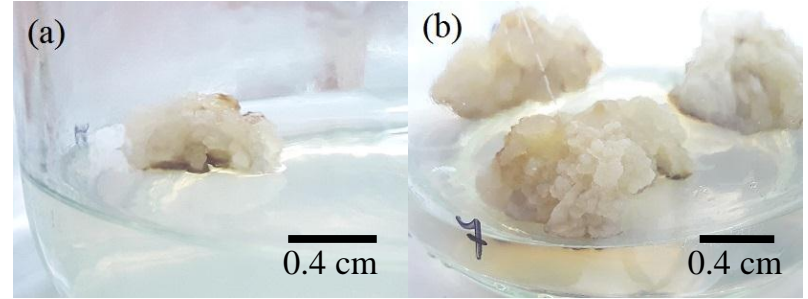

Fig 4. growth of callus from petiole explant cultured on $0.5 \mathrm{mg} / \mathrm{L}$ $\mathrm{BAP}+1.0 \mathrm{mg} / \mathrm{L}$ NAA (a) for 4 week (b) for 8 week.

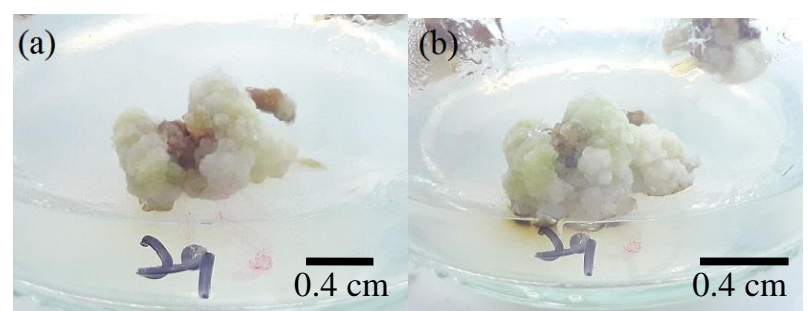

Fig. 5 growth of callus from root explant cultured on $1.0 \mathrm{mg} / \mathrm{L} \mathrm{BAP}+$ $1.0 \mathrm{mg} / \mathrm{L} \mathrm{NAA} \mathrm{(2)} \mathrm{for} 4$ week (b) for 8 week.

The formation of callus with an explant marks the beginning of a successful plant tissue culture [9]. Sharma [12] stated that the used of BAP and NAA were significantly affected to the callus and shoot growth. Thus, in study showed that all parts of of Ficus carica explants tested were able to undergo in vitro micropropagation and might be used for a variety of experiment in the future.

\section{CONCLUSION}

Overall, this study providess the efficient and reproducible solution on clonal production of Ficus carica. Propagation of plants through tissue culture system possibly act as an alternative way to the conventional planting process. Furthermore, these study also may help the tissue culture industries to get an economic impact on the mass production and germplasm conservation.

\section{REFERENCES}

[1] Al-snafi, A. E. (2017). Nutritional and pharmacological importance of Ficus carica. Journal of Pharmacy, 7(3), 22-48. https://doi.org/10.9790/3013-0703013348

[2] Barolo, M. I., Mostacero, N. R., \& López, S. N. (2014). Ficus carica L . ( Moraceae ): An ancient source of food and health. Food Chemistry, 164, 119-127. https://doi.org/10.1016/j.foodchem.2014.04.112

[3] Bayoudh, C., Labidi, R., Majdoub, A., \& Mars, M. (2015). In vitro Propagation of Caprifig and Female Fig Varieties (Ficus carica L.) from Shoot-tips. Journal Agricultural Science Technology, 17, 1597-1608.

[4] Danial, G. H., Ibrahim, D. A., Brkat, S. A., \& Khalil, B. M. (2014). Multiple Shoots Production from Shoot Tips of Fig Tree ( Ficus carica L.) and Callus Induction from Leaf Segments, 20(1), 117-124.

[5] Darwesh, H. Y., Bazaid, S. A., \& Samra, B. N. A. (2014). In vitro propagation method of Ficus carica at Taif governorate using tissue culture technique. International Journal of Advanced Research, 2(6), 756-761.

[6] Dessoky, E. S., Attia, A. O., \& Mohamed, E. A. M. (2016). An efficient protocol for in vitro propagation of Fig (Ficus carica sp) and evaluation of genetic fidelity using RAPD and ISSR markers. Journal of Applied Biology and Biotechnology, 4(04), 57-63.

[7] FAOSTAT. (2017). Retrieved on 1 Nov 2017 from http://www.fao.org/faostat/en/
[8] Hesami, M., Daneshvar, M. H., Yoosefzadeh-Najafabadi, M., \& Alizadeh, M. (2018). Effect of plant growth regulators on indirect shoot organogenesis of Ficus religiosa through seedling derived petiole segments. Journal of Genetic Engineering and Biotechnology, 16(1), $175-180$. https://doi.org/10.1016/j.jgeb.2017.11.001

[9] Inês, M., João, M., Alves, R. C., \& Ferreira, I. C. F. R. (2016). Exploring plant tissue culture to improve the production of phenolic compounds : A review. Industrial Crops \& Products, 82, 9-22. 6 https://doi.org/10.1016/j.indcrop.2015.12.016

[10] Oberhue, C. (2017). Top Fig Growing Countries. Wordatlas. Retrieved on 2 Nov 2017 from http://www.worldatlas.com/articles/top-fig-growing-countries.html

[11] Oguzhan, C., \& Polat, A. A. (2012). Morphological diversity among fig ( Ficus carica L .) accessions sampled from the Eastern Mediterranean Region of Turkey. Turk J Agric For, 36, 179-193.

[12] Sharma, H. (2017). Growth Regulators in Micropropogation of Woody Olants. International Journal of Advanced Reserche, 5(2), 2378-2385 https://doi.org/10.21474/IJAR01/3421

[13] Shomali, I. A.-, Sadder, M. T., \& Ateyyeha, A. (2017). Culture Media Comparative Assessment of Common Fig (Ficus carica L.) and Carryover Effect. Jordan Journal of Biological Science, 10(1), 13-18.

[14] Singh, B. M., Rajoriya, C. M., Wani, I. A., Rawat, R. S., \& Jat, B. L. (2016). In Vitro Studies of Ficus carica and its Application. International Jounal for Research in Applied Science and Engineering Technology, 4(11), 135-148.

[15] USDA. (2017). Food Composition and Databases Show Food. Retrieved on 2 Nov 2017 from https://ndb.nal.usda.gov/ndb/food/show/2201 